\title{
ABORTION POLITICS: WRITING FOR AN AUDIENCE OF ONE
}

\section{Susan R. Estrich† and Kathleen M. Sullivan††}

\section{Introduction: Webster ANd the Art of Spin Control}

"Spin doctors," as they came to be known in the last presidential campaign, practice a not-so-fine art of press manipulation. The goal is generally to make bad news hurt less (e.g." "third in Iowa, my God, we're delighted; it's a springboard for New Hampshire!') and good news help more (e.g., "the real test will be in . . . [pick state where you've already spent twice as much as the opposition]"). The press generally knows the doctors are working ("what's your spin?" or "spin me" the reporters say), but the process works anyway, particularly if the spinners can look appropriate in the end (e.g., "aides were plainly pleased with their candidates third place finish . ....").

Lawyers, of course, have been "spinning" judicial decisions for years. In court, it's called advocacy. Rarely, though, has a court decision been "spun" as forcefully and effectively as the United States Supreme Court's decision last Term in Webster v. Reproductive Health Services. ${ }^{1}$ The spin was, surprisingly, the same on both sides. The right-to-lifers said victory was at hand. The pro-choicers said the sky was falling.

What was most surprising about this, at least at first glance, was that it bore almost no relation to what had actually been decided in Webster. Which was, according to all sides of the Court, at least, not much. As Justice Blackmun put it, "[f]or today, at least, the law of abortion stands undisturbed."2 Or as Justice Scalia wrote, with obvious scorn, the Court, and Justice O'Connor in particular, succeeded in their determination "to avoid almost any decision of national import."3

As the Court construed them, Webster's three particular issues fit well within previous regulations upheld by the Court. The majority

$\dagger$ Professor of Law, Harvard University. B.A. 1974, Wellesley College; J.D. 1977, Harvard University.

t† Professor of Law, Harvard University. B.A. 1976, Cornell University; B.A. 1978, Oxford University; J.D. 1981, Harvard University.

1109 S. Ct. 3040 (1989).

2 Id. at 3079 (Blackmun, J., dissenting).

3 Id. at 3064 (Scalia, J., concurring in part and concurring in judgment). 
was able to avoid any ruling at all on Missouri's declaration that life begins at conception by concluding that the passage merely expressed a value judgment. Restrictions on using public facilities for abortion, particularly as narrowly although perhaps inaccurately framed by the state's Attorney General, fit within the Court's precedents upholding the exclusion of public support for abortion. Finally, the state's seeming viability testing requirement at twenty weeks or more became, with a little interpretive twisting, no more than a recommendation that doctors perform such tests where medically appropriate.

Of course, if little was decided in Webster, a good deal was nonetheless said. The Chief Justice, writing for three members of the Court, made plain that he was ready to jettison Roe trimester approach of Roe $v$. Wade, ${ }^{4}$ presumably finding the state's interest in potential life as compelling in the first month as the last, and leaving it to the state to balance its own interest against the woman's, subject only to some rationality review. The genius of the approach, if you can call it that, is that it effectively overrules Roe without ever even suggesting that a woman lacks a privacy or autonomy interest in her own body.

From the looks of things, the approach was crafted with the hopes of winning five votes for an opinion that would have more than earned all the hoopla that Webster garnered. Justice O'Connor, however, was more stubborn than many expected or dared hope. While voting to uphold the regulations, as she always has in abortion cases, she refused to seize the opportunity to review anything broader than the statute before her: "When the constitutional invalidity of a State's abortion statute actually turns on the constitutional validity of Roe $v$. Wade, there will be time enough to reexamine Roe. And to do so carefully."5

Justice Scalia, who recognized that Chief Justice Rehnquist's approach would effectively overrule Roe, but preferred to do so "more explicitly," ridiculed Justice O'Connor's self-described efforts at "statesmanship." He pointed out each of her opinions from this Term that in fact "formulate[d] a rule of constitutional law broader than required by the precise facts to which it is to be applied"6 precisely what she refused to do here.

4410 U.S. 113 (1973).

5 Webster, $109 \mathrm{~S}$. Ct. at 3061 (O'Connor, J., concurring in part and concurring in judgment).

6 Id. at 3064 (Scalia, J., concurring in part and concurring in judgment). 
All of this left the abortion question, unfortunately, pretty much where most sophisticated Court-watchers (did anyone really doubt how Justice Kennedy would vote) thought it would be: with four firm votes to reaffirm and four poised to eviscerate Roe, but with Justice O'Connor more resistant to that onslaught than many of us dared hope. Not good news, to be sure, particularly considering the dissenters' average age and last November's election results, but was the sky falling? Or rather, were things any worse than they had been a day or a week or six months before?

The right-to-lifers plainly had every incentive to claim a major victory in Webster; it's the old strategy of making basically good or at least O.K. news help more: keeping that "Big Mo" rolling as our President used to say. The pro-choice strategy was a little different. Conventional wisdom usually advises downplaying your defeats: the "more of the same" and "the big test is still ahead, nothing new here folks" line. For the pro-choice movement, though, these are not conventional times.

Long outflanked, in terms of outward signs of energy, command of the debate, and fear inspired in politicians, the pro-choice forces had fastened on Webster as a rallying point. The United States government's much-publicized decision to use Webster as an occasion to challenge Roe was the spark. The chances of the government actually succeeding were, to be sure, slim. The government had tried precisely the same strategy before, and even after Justice Kennedy's appointment, it was likely one vote short. ${ }^{7}$ Still, and for the first time, pro-choice voters were shedding their complacency.

All of these factors presented the pro-choice side with an obvious opportunity, but also a real danger. The danger was, quite simply, that a decision like Webster would lead the newly or about-to-be activated to conclude that the past months' political efforts had been so much ado about nothing. The July 3rd "spin" plainly avoided that danger. The losers, like the winners, described Webster as a major turning point. Both sides were saying the same thing, albeit for different reasons. And when that happens, the spin is the news. For better or worse- and we think and hope, for the better-American politics may never be quite the same. The abortion issue is on the table. The great, silent majority that is pro-choice, or at least

7 See Brief for the United States as Amicus Curiae in Support of Petitioners, Thornburgh v. American College of Obstetricians \& Gynecologists, 476 U.S. 747 (1985) (No. 84-495). 
anti-government, has been scared into action. All by a Supreme Court case that decided nothing at all.

There are, to be sure, some dangers to this strategy. The most serious is that people who should know better might actually believe the hype. Legislators who have been happily hiding behind the Supreme Court and "the law of the land" have lost their cover, if not because of the Supreme Court's actions, then because of the country's perception. Governors seem to think that Webster justifies special legislative sessions to restrict abortion rights. And worst of all, some judges may mistake the hoopla for precedent and conclude that the televised analyses, particularly by law professors, should be the basis for their opinions.

Still, from a political point of view, the choice seems clearly right. Complicated arguments about pluralities, concurrences, undue burdens, and strict scrutiny are hardly the stuff of political debate. The language of politics is very different from the language of law; and if anyone still doubts that, ask them whether we should require schoolteachers to lead the pledge of allegiance in class, or whether we should give murderers weekend furloughs. The decision to move into the political debate, and to do so with a cry of alarm if not desperation, fairly reflects the fact that the pro-choice position can no longer routinely command a majority of the Supreme Court. We knew that before Webster. It just provided the opportunity to say so loudly.

But that does not mean that it is time to abandon the Court. We cannot afford to. That is the very point that pro-choice advocates have been making in the Court for most of the last twenty years: even if we are better organized now, leaving these decisions to state legislatures, means that some women will lose their rights. The ability to choose will once again depend upon who you are and where you live and how much money you have; and young and poor women, for whom the burden of an unwanted pregnancy is most crushing, will have the fewest rights of all. The bottom line isn't spin; and we forget it at our peril.

And so we will return to the Supreme Court, this Term and no doubt next and the one after, and notwithstanding what our colleagues said on television, we will say that Webster decided nothing at all.

But it certainly did make one thing clear: eight men may read our briefs, but the real audience is one woman. Sandra Day O'Connor, the only woman in American history to sit on the United 
States Supreme Court, is in the position single-handedly to decide the future of abortion rights.

This Article is not an effort to "spin" anyone. It is nothing more or less than our best try, using whatever legal and persuasive talents we have, to convince an audience of one to stand up to those who are turning their backs on women.

Where exactly does Justice O'Connor hold the cards? In the streets, the dispute takes blunt form: to some demonstrators, abortion is murder; to others, no women should ever wind up in the back alley again. In court, the debate is more refined. Three basic issues divide the post-Roe Court. The first is whether there is an underlying fundamental right to choose abortion. The second is what counts as government infringement of that right. The third is when such infringement may be justified. After Roe, controversy swirled around the first. After Webster, the first has been eclipsed by the second and third. And it is on the second and third issues that Justice O'Connor's is the pivotal vote.

\section{The Existence of A Liberty INTEREST}

Roe v. Wade held the "right of privacy ... founded in the Fourteenth Amendment's concept of personal liberty and restrictions upon state action, . . . broad enough to encompass a woman's decision whether or not to terminate her pregnancy."8 That recognition appears, sixteen years later, far less controversial than it did at the time. The most recent efforts to eviscerate Roe, most notably the Chief Justice's opinion in Webster, do not deny the liberty interest's existence, but rather effectively deny the court's obligation to protect it with strict scrutiny. ${ }^{9}$

8410 U.S. 113,153 (1973).

9 The Chief Justice and Justice White have previously disputed Roe's premise that a woman's right to control pregnancy is fundamental. See Roe, 410 U.S. at 17273 (Rehnquist, J., dissenting) (stating that even if there were a "liberty" interest of persons to be free from unwanted state regulation of consensual transactions, "that liberty" is guaranteed "only against deprivation without due process of law; [ $t$ ] traditionally applied in the area of social and economic legislation is whether or not a law such as that challenged has a rational relation to a valid state objective."); Doe v. Bolton, 410 U.S. 179, 222 (1973) (White, J., dissenting) ("I cannot accept the Court's exercise of its clear power of choice by interposing a constitutional barrier to state efforts to protect human life and by investing mothers and doctors with the Constitutionally protected right to exterminate it."); Thornburgh v. American College of Obstetricians \& Gynecologists, 476 U.S. 747, 790 (1985) (White, J., dissenting) ("I can certainly agree with the proposition ... that a woman's ability to choose an abortion is a species of 'liberty' that is subject to the general protections of the Due Process Clause. I cannot agree, however, that this liberty is so 'fundamental' 
Still, it seems important, at the outset, to revisit the case for Roe's recognition of a fundamental liberty interest. ${ }^{10}$ If the Roe analysis is now accepted wisdom, as it appears and should be, then the onslaught on the scrutiny question becomes even more clearly hypocritical. Standard constitutional practice requires applying strict scrutiny to government restrictions on fundamental rights. ${ }^{11}$

that restrictions upon it call into play anything more than the most minimal judicial scrutiny."), but only Justice Scalia took that route in Webster, $109 \mathrm{~S}$. Ct. at 3064-67 (Scalia, J., concurring in part and concurring in judgment) (staunchly advocating reexamining Roe).

$10 \mathrm{~A}$ number of commentators have also argued persuasively that abortion restrictions discriminate on the basis of gender, and that heightened scrutiny ought be applied on that basis as well. See, e.g., Ginsburg, Some Thoughts on Autonomy and Equality in Relation to Roe v. Wade, 63 N.C.L. Rev. 375 (1985); Law, Rethinking Sex and the Constitution, 132 U. PA. L. Rev. 955 (1984). One might think that Geduldig v. Aiello, 417 U.S. 484 (1974), precludes this argument. Geduldig upheld a state disability insurance program that excluded from coverage certain disabilities resulting from pregnancy. The Court reasoned that excluding "pregnant women" from benefits accruing to "nonpregnant persons" was not a gender-based classification. Id. at 496-97 n.20. The Geduldig program, however, is distinguishable from abortion restrictions along lines that now-Chief Justice Rehnquist drew shortly afterward. In Nashville Gas Co. v. Satty, 434 U.S. 136, 142 (1977) (deeming exclusion of pregnant employees sex discrimination under Title VII), then-Justice Rehnquist drew a distinction between "merely refus[ing] to extend to women a benefit that men cannot and do not receive," as in Geduldig, and "impos[ing] on women a substantial burden that men need not suffer," as in Satty. Although this distinction between non-benefits and burdens is misconceived, it at least suggests that Geduldig does not bar heightened scrutiny of abortion restrictions as sex discrimination. On this theory, abortion restrictions constitute sex-based classifications no less than would a law forbidding pregnant women to appear in public. Cf. Cleveland Bd. of Educ. v. LaFleur, 414 U.S. 632, 647-48 (1974) (invalidating under the due process clause a school board regulation that required pregnant school teachers to take unpaid maternity leave five months before childbirth); see id. at 651-53 (Powell, J., concurring on equal protection grounds).

Moreover, the "fundamental rights" branch of the Court's equal protection jurisprudence suggests that not only heightened, but strict scrutiny would be necessary. Where legislatures classify in a way that imposes unequal burdens on basic interests in bodily integrity, procreation, health, and family, the Court has held such classifications subject to strict review. See, e.g., Skinner v. Oklahoma, 316 U.S. 535, 541 (1942) (applying strict scrutiny under the Equal Protection Clause to a compulsory sterilization law that discriminated among categories of criminals, a kind of line-drawing that otherwise would not have been suspect); Zablocki v. Redhail, 434 U.S. 374, 388 (1978) (applying strict scrutiny under the Equal Protection Clause to a marriage restriction that discriminated against persons with outstanding child support obligations, a classification that would normally have been deferentially reviewed).

11 This section draws heavily from an amicus curiae brief we prepared on behalf of various groups in Turnock v. Ragsdale, 841 F.2d 1358 (7th Cir. 1988), cert. granted, 57 U.S.L.W. 3859 (U.S. July 3, 1989), and Ohio v. Akron Center for Reproductive Health, prob. jurisdiction noted, 109 S. Ct. 3239 (1989), two of the abortion cases 


\section{A. Reproductive Choice is Essential to a Woman's Control of Her Destiny and Family Life}

Notwithstanding the abortion controversy, the Supreme Court has long acknowledged an unenumerated right to privacy as a species of "liberty" that the due process clauses protect. ${ }^{12}$ The principle is as ancient as Meyer $v$. Nebrask $a^{13}$ and Pierce $v$. Society of Sisters, ${ }^{14}$ which protected parents' freedom to educate their children free of the state's controlling hand. In its modern elaboration, this right continues to protect child rearing and family life from the overly intrusive reach of government. ${ }^{15}$ The modern privacy cases have also plainly established that decisions whether to bear children are no less fundamental than decisions about how to raise them. The Court has consistently held since Griswold $v$. Connecticut ${ }^{16}$ that the Constitution accords special protection to "matters so fundamentally affecting a person as the decision whether to bear or beget a child," and has therefore strictly scrutinized laws restricting contraception. ${ }^{17}$ Roe held that these principles extend no less to abortion than to contraception.

The privacy cases rest, as Justice Stevens recognized in Thormburgh, centrally on " 'the moral fact that a person belongs to himself [or herself] and not others nor to society as a whole." 18 Extending this principle to the abortion decision follows from the fact that "[f]ew decisions are ... more basic to individual dignity and auto-

pending in the United States Supreme Court at the outset of the current term. Ragsdale has since settled.

12 The right of privacy is only one among many instances in which the Court has recognized rights that are not expressly named in the Constitution's text. To name just a few other examples, the Court has recognized unenumerated rights to freedom of association, see National Association for the Advancement of Colored People v. Alabama, 357 U.S. 449, 466 (1958); to equal protection under the fifth amendment due process clause, see Bolling v. Sharpe, 347 U.S. 497, 500 (1954); to travel between the states, see Shapiro v. Thompson, 394 U.S. 618, 638 (1966); to vote, see Harper v. Virginia Bd. of Elections, 383 U.S. 663, 665-66 (1966); Reynolds v. Sims, 377 U.S. 533, 554 (1964); and to attend criminal trials, see Richmond Newspapers Inc. v. Virginia, 448 U.S. 555, 579-80 (1980).

13262 U.S. 390 (1923).

14268 U.S. 510 (1925).

15 See, e.g., Moore v. City of East Cleveland, 431 U.S. 494, 503-06 (1977) (plurality opinion) (noting a constitutional right to live with one's grandchildren); Loving v. Virginia, 388 U.S. 1, 12 (1967) (affirming a right to interracial marriage).

16381 U.S. 479 (1965).

17 Eisenstadt v. Baird, 405 U.S. 438, 453 (1972).

18 Thornburgh v. American College of Obstetricians \& Gynecologists, 476 U.S. 747, 777 n.5 (1985) (Stevens, J., concurring) (quoting former Solicitor General Fried, Correspondence, 6 Phil. \& PuB. Aff. 288-89 (1977)). 
nomy" or more appropriate to the "private sphere of individual liberty" than the uniquely personal, intimate, and self-defining decision whether or not to continue a pregnancy. ${ }^{19}$

In two senses, abortion restrictions keep a woman from "belonging to herself." First and most obviously, they deprive her of bodily self-possession. As Chief Justice Rehnquist observed in another context, pregnancy entails "profound physical, emotional, and psychological consequences." 20 To name a few, pregnancy increases a woman's uterine size 500-1000 times, her pulse rate by ten to fifteen beats a minute, and her body weight by 25 pounds or more. ${ }^{21}$ Even the healthiest pregnancy can entail nausea, vomiting, more frequent urination, fatigue, back pain, labored breathing, or water retention. ${ }^{22}$ There are also numerous medical risks involved in carrying pregnancy to term: of every ten women who experience pregnancy and childbirth, six need treatment for some medical complication, and three need treatment for major complications. ${ }^{23}$ In addition, labor and delivery impose extraordinary physical demands, whether over the six to twelve hour or longer course of vaginal delivery, or during the highly invasive surgery involved in a cesarean section, which accounts for one out of four deliveries. ${ }^{24}$

By compelling pregnancy to term and delivery even where they are unwanted, abortion restrictions thus exert far more profound intrusions into bodily integrity than the stomach-pumping the Court invalidated in Rochin v. Califormia, ${ }^{25}$ or the surgical removal of a bullet from a shoulder that the Court invalidated in Winston v. Lee. ${ }^{26}$ "The integrity of an individual's person is a cherished value of our society" 27 because it is so essential to identity; as former Solicitor General Charles Fried, who argued for the United States in Webster,

19 Thomburgh, 476 U.S. at 772.

20 Michael M. v. Sonoma County Superior Court, 480 U.S. 464, 471 (1981).

21 See J. Pritchard, P. McDonaid \& N. Gant, Williams Obstetrics 181-210, 260-63 (17th ed. 1985) [hereinafter Williams OBSTETRICs].

22 See id.

23 See R. Gold, A. Kenney \& S. Singh, Blessed Events and the Bottom Line: Financing Maternity Care in the United States 10 (1987).

24 See D. Danforth, M. Hughey \& A. Wagner, The Complete Guide to Pregnancy 228-3 I (1983); S. Romney, M.J. Gray, A.B. Little, J. Merrill, E.J. Quilligan \& R. Stander, Gynecology and Obstetrics: The Health Care of WOMEN 626-37 (2d ed. 1981).

25342 U.S. 165 (1952).

26470 U.S. 753 (1985).

27 Id. at 760. 
recognized in another context: "[to say] that my body can be used is [to say] that I can be used." 28

These points would be too obvious to require restatement if the state attempted to compel abortions rather than to restrict them. Indeed, in colloquy with Justice O'Connor during the Webster oral argument, former Solicitor General Fried conceded that in such a case, liberty principles, although unenumerated, would compel the strictest review. To be sure, as Mr. Fried suggested, restrictive abortion laws do not literally involve "laying hands on a woman."29 But this distinction should make no difference: the state would plainly infringe its citizens' bodily integrity whether its agents inflicted knife wounds or its laws forbade surgery or restricted blood transfusions in cases of private knifings. ${ }^{30}$

Apart from this impact on bodily integrity, abortion restrictions infringe à woman's autonomy in a second sense as well; they invade the autonomy in family affairs that the Supreme Court has long deemed central to the right of privacy. Liberty requires independence in making the most important decisions in life. ${ }^{31}$ "The decision whether or not to beget or bear a child" lies at "the very heart of this cluster of constitutionally protected choices," 32 because few decisions can more importantly alter the course of one's life than the decision to bring a child into the world. Bearing a child dramatically affects " "what a person is, what [s] he wants, the determination of [her] life plan, of [her] concept of the good' "' and every other aspect of the "self-determination ... [that] give[s] substance to the concept of liberty." "33 Becoming a parent dramatically alters a woman's educational prospects, ${ }^{34}$ employment opportunities, ${ }^{35}$ and sense of

28 C. Fried, Right and Wrong 121 n.* (1978).

29 Transcript of Oral Argument in Abortion Case, N.Y. Times, Apr. 27, 1989, at B12, col. 5 .

30 Likewise, a state would surely infringe reproductive freedom by compelling abortions even if it became technologically possible to do so without "laying hands on a woman."

31 See Whalen v, Roe, 429 U.S. 589, 599-600 (1977).

32 Carey v. Population Serv. Int'l, 431 U.S. 678, 685 (1977).

33 Thornburgh v. American College of Obstetricians \& Gynecologists, 476 U.S. 747,777 n.5 (1985) (Stevens, J., concurring) (quoting C. Fried, Right AND Wrong $146-47$ (1978)).

34 Teenage mothers have high dropout rates: eight out of ten who become mothers at age seventeen or younger do not finish high school. See Fielding, Adolescent Pregnancy Revisited, 299 Mass. Dep't Pub. Health 893, 894 (1978).

35 Control over the rate of childbirth is a key factor in explaining recent gains in women's wages relative to men's. See Fuchs, Women's Quest for Economic Equality, $3 \mathrm{~J}$. ECon. Persp. 25, 33-37 (1989). 
self. ${ }^{36}$ In light of these elemental facts, it is no surprise that the freedom to choose one's own family formations is "deeply rooted in this Nation's history and tradition."37

Today, virtually no one disputes that these principles require heightened scrutiny of laws restricting access to contraception. ${ }^{38}$ But critics of Roe sometimes argue that abortion is "different in kind from the decision not to conceive in the first place."39 Justice White, for example, has asserted that, while the liberty interest is fundamental in the contraception context, ${ }^{40}$ that interest falls to minimal after conception. ${ }^{41}$

Such a distinction cannot stand, however, because no bright line can be drawn between contraception and abortion in light of modern scientific and medical advances. Contraception and abortion are points on a continuum. Even "conception" itself is a complex process of which fertilization is simply the first stage. According to contemporary medical authorities, conception begins not with fertilization, but rather six to seven days later when the fertilized egg becomes implanted in the uterine wall, itself a complex process. ${ }^{42}$ Many medically accepted contraceptives operate after fertilization. For example, both oral contraceptives and the intra-uterine device

36 This fact is evident even if the biological mother does not raise her child. Relinquishing a child for adoption may alleviate material hardship, but it is psychologically traumatic. See Winkler \& VanKeppel, Relinquishing Mothers in Adoption: Their Long-Term Adjustment, Monograph No. 3, Institute of Family Studies (1984).

37 Moore v. City of East Cleveland, 431 U.S. 494, 503 (1977) (plurality opinion).

38 The United States has conceded before the Supreme Court that the Griswold line of cases was correctly decided. See Brief for the United States as Amicus Curiae Supporting Appellants, 11-13, Webster v. Reproductive Health Serv., $1109 \mathrm{~S}$. Ct. 3040 (1989) (No. 88-605); Transcript of Oral Argument in Abortion Case, N.Y. Times, Apr. 27, 1989, at B 13, col. 1 (Argument of former Solicitor General Fried on behalf of the United States).

39 Thornburgh, 476 U.S. at $792 \mathrm{n} .2$ (White, J., dissenting).

40 See Eisenstadt v. Baird, 405 U.S. 438, 463-64 (1972) (White, J., concurring in result); Griswold v. Connecticut, 381 U.S. 479, 502-03 (1965) (White, J., concurring in judgment).

41 See Thornburgh, 476 U.S. at 792 n.2 (White, J., dissenting) (arguing that the fetus' presence after conception changes not merely the state justification but "the characterization of the liberty interest itself").

42 See Williams Obstetrics, supra note 21, at 88-91; Milby, The New Biology and the Question of Personhood: Implications for Abortion, 9 AM. J.L. \& MED. 31, 39-41 (1983). Indeed, the American College of Obstetricians \& Gynecologists, the pre-eminent authority on such matters, has adopted the following official definition of conception: conception consists of "the implantation of the blastocyst [fertilized ovum]" in the uterus, and thus is "not synonymous with fertilization." OBSTETRIC-GYNecologic Terminology 229, 327 (E. Hughes ed. 1972). Such a definition is not surprising in view of the fact that less than half of fertilized ova ever successfully become implanted. See Post-Coital Contraception, 1 The LanCET 855, 856 (1983). 
(IUD) not only prevent fertilization but in some instances prevent implantation. ${ }^{43}$ Moreover, the most significant new developments in contraceptive technology, such as RU486, act by foiling implantation. ${ }^{44}$ All such contraceptives blur the line between contraception and abortion.

In the absence of a bright physiological line, there can be no bright constitutional line between the moments before and after conception. A woman's fundamental liberty does not simply evaporate when sperm meets ovum. Indeed, as Justice Stevens has recognized, "if one decision is more 'fundamental' to the individual's freedom than the other, surely it is the postconception decision that is the more serious." 45 Saying this much does not deny that profound evolutionary changes occur between fertilization and birth. Clearly, there is some difference between "the freshly fertilized egg and ... the 9-month-gestated . . . fetus on the eve of birth."46 But as Roe $v$. Wade fully recognized, such differences go at most to the weight of the state's justification for interfering with a pregnancy; they do not extinguish the underlying fundamental liberty.

Thus Roe is not a mere "thread" that the Court could pull without "unravel[ing]" the now elaborately woven "fabric" of the privacy decisions. ${ }^{47}$ Rather, Roe is integral to the principle that childbearing decisions come to "th[e] Court with a momentum for respect that is lacking when appeal is made to liberties which derive merely from shifting economic arrangements."48 The decision to become a mother is too fundamental to be equated with the decision to buy a car, choose optometry over ophthalmology, take early retirement, or

43 See R. Hatcher, E. Guest, F. Stewart, G. Stewart, J. Trussell, S. Bowen \& W. Cates, Contraceptive Technology 252-53, 377 (14th rev. ed. 1988) [hereinafter Contraceptive Technology]; United States Department of Health and Human Services, IUDs: Guidelines for Informed Decision-Making and Use (1987).

44 See Contraceptive Technology, supra note 43, at 378; Nieman, Choate, Chrousas, Healy, Morin, Renquist, Merriam, Spitz, Bardin, Balieu \& Loriaux, The Progesterone Antagonist RU486: A Potential New Contraceptive Agent, 316 N. ENG. J. MEd. 187 (1987). RU486 is approved for use in France but not in the United States.

45 Thomburgh, 476 U.S. at 776 (Stevens, J., concurring).

46 Id. at 779.

47 Transcript of Oral Argument in Abortion Case, N.Y. Times, April 27, 1989, at B12, col. 5 (former Solicitor General Fried, arguing on behalf of the United States). Counsel for Appellees gave the following complete reply: "It has always been my personal experience that when I pull a thread, my sleeve falls off." Id. at B13, col. I (argument of Mr. Susman).

48 Thornburgh, 476 U.S. at 775 (Stevens, J., concurring) (citing Griswold v. Connecticut, 381 U.S. 479, 502-03 (1965) (White, J., dissenting)). 
any other merely economic decision that the government may regulate by showing only a minimally rational basis.

\section{B. Keeping Reproductive Choice in Private Hands is Essential to a Free Society}

Even if there were any disagreement about the degree of bodily or decisional autonomy that is essential to personhood, there is a separate, alternative rationale for the privacy cases: keeping the state out of the business of reproductive decision-making. Regimentation of reproduction is a hallmark of the totalitarian state, from Plato's Republic to Hitler's Germany, from Huxley's Brave New World to Atwood's Handmaid's Tale. Whether the state compels reproduction or prevents it, "totalitarian limitation of family size ... is at complete variance with our constitutional concepts."49 The state's monopoly of force cautions against any official reproductive orthodoxy.

For these reasons, the Supreme Court has long recognized that the privacy right protects not only the individual but also our society. As early as Meyer ${ }^{50}$ and Pierce, ${ }^{51}$ the Court acknowledged that " $[t]$ he fundamental theory of liberty" on which a free society rests "excludes any general power of the State to standardize" its citizens. ${ }^{52}$ As Justice Powell likewise recognized for the Moore plurality, "a free society" is one that avoids the homogenization of family life. ${ }^{53}$

The right of privacy, like freedoms of speech and religion, protects conscience and spirit from the encroachment of overbearing government. "Struggles to coerce uniformity of sentiment," Justice Jackson recognized in West Virginia State Board of Education v. Barnette, ${ }^{54}$ are the inevitably futile province of "our totalitarian enemies." 55 Preserving a private sphere for childbearing and childrearing decisions not only liberates the individual; it desirably constrains the state. ${ }^{56}$

Those who would relegate all control over abortion to the state

49 Griswold, 381 U.S. 497 at (Goldberg, J., concurring).

50 Meyer v. Nebraska, 262 U.S. 390 (1923).

51 Pierce v. Society of Sisters, 268 U.S. 510 (1925).

52 Id. at 535.

53 See Moore v. City of East Cleveland, 431 U.S. 494, 503 n.11 (1977) (quoting from a discussion of Griswold in Pollak, Thomas I. Emerson, Lawyer and Scholar: Ipse Custodiet Custodes, 84 YALE L.J. 638, 653 (1975)).

54319 U.S. 624 (1943).

$55 \mathrm{Id}$. at $640-41$.

56 See generally Rubenfeld, The Right of Privacy, 102 Harv. L. Rev. 737, 804-07 (1989) (arguing that the constitutional right of privacy protects individuals from 
legislatures ignore these fundamental, systemic values. It is a red herring to focus on the question of judicial versus legislative control of reproductive decisions, as so many of Roe's critics do. The real distinction is that between private and public control of the decision: the private control that the courts protect through Griswold and Roe, and the public control that the popular branches could well usurp in a world without those decisions.

Precisely because of the importance of a private sphere for family, spirit, and conscience, the Framers never intended to commit all moral disagreements to the political arena. Quite the contrary:

The very purpose of a Bill of Rights was to withdraw certain subjects from the vicissitudes of political controversy, to place them beyond the reach of majorities and officials and to establish them as legal principles to be applied by the courts. One's right to life, liberty, and property, to free speech, a free press, freedom of worship and assembly, and other fundamental rights may not be submitted to vote; they depend on the outcome of no elections. ${ }^{57}$

Such "withdrawal" of fundamental liberties from the political arena is basic to constitutional democracy as opposed to rank majoritarianism, and nowhere is such "withdrawal" more important than in controversies where moral convictions and passions run deepest. The inclusion of the free exercise clause attests to this point. ${ }^{58}$

The Framers also never intended that toleration on matters of family, conscience, and spirit would vary from state to state. The value of the states and localities as "laborator[ies for] ... social and economic experiments," 59 has never extended to " "experiments at the expense of the dignity and personality' of the individual." "60

being turned into instrumentalities of the regimenting state, or being forced into a state-chosen identity).

57 Barnette, 319 U.S. at 638.

58 Justice Douglas wrote:

The Fathers of the Constitution were not unaware of the varied and extreme views of religious sects, of the violence of disagreement among them, and of the lack of any one religious creed on which all men would agree. They fashioned a charter of government which envisaged the widest possible toleration of conflicting views.

United States v. Ballard, 322 U.S. 78, 87 (1944). See also Webster, 109 S. Ct. at 3085 \& n.16 (Stevens, J., concurring in part and dissenting in part) (noting that "the intensely divisive character of much of the national debate over the abortion issue reflects the deeply held religious convictions of many participants in the debate").

59 New State Ice Co. v. Liebmann, 285 U.S. 262, 311 (1932) (Brandeis, J., dissenting).

60 Poe v. Ullman, 367 U.S. 497, 555 (1961) (Harlan, J., dissenting) (quoting Skinner v. Oklahoma, 316 U.S. 535, 546 (1942) (Jackson, J., concurring)). 
Rather, as Madison once warned, "it is proper to take alarm at the first experiment on our liberties. We hold this prudent jealousy to be the first duty of citizens, and one of [the] noblest characteristics of the late Revolution." "61

Roe v. Wade thus properly withdrew the abortion decision, like other decisions on matters of conscience, "from the vicissitudes of political controversy." It did not withdraw that decision from the vicissitudes of moral argument or social suasion by persuasive rather than coercive means. ${ }^{62}$ In withdrawing the abortion decision from the hot lights of politics, Roe protected not only persons but the processes of constitutional democracy.

\section{Strict Scrutiny}

The scrutiny to be afforded government restrictions on abortion has emerged, at least in the Court in recent years, as far more controversial than the existence of the underlying liberty interest itself. At the threshold, there is the question whether all abortion restrictions should be subject to strict scrutiny. Justice O'Connor, most notably, has argued that only those restrictions that "unduly burden" the abortion right should trigger strict scrutiny. There is also the question of what governmental interests may be sufficiently "compelling" to justify restrictions, and even more to the point, whether interests in maternal health and potential life are compelling throughout pregnancy or, as Roe held, whether they grow as pregnancy proceeds.

Formally, these are questions of scrutiny. Practically, they are much more. Depending on their answers, the Justices could wholly eviscerate Roe's fundamental liberty interest—without ever formally questioning its existence.

In her most detailed statement on abortion, a 1983 dissent in City of Akron v. Akron Center for Reproductive Health, ${ }^{63}$ Justice O'Connor sharply criticized Roe's trimester approach. She argued that it "cannot be supported as a legitimate or useful framework for accommodating the woman's right and the State's interests."64 Three years later, dissenting in Thomburgh v. American College of Obstetricians $\mathcal{F}^{\circ}$

61 Everson v. Board of Educ., 330 U.S. 1, 65 (1947) (Appendix, Rutledge, J., dissenting) (quoting Madison, Memorial and Remonstrance Against Religious Assessments).

62 Nor, of course, did it bar political efforts to reduce the abortion rate through non-coercive means, such as funding sex education and contraception, or providing economic security to indigent mothers.

63462 U.S. 416, $452-75$ (1983) (O'Connor, J., dissenting).

64 Id. at 454 (O'Connor, J., dissenting). 
Gynecologists, ${ }^{65}$ Justice O'Connor concluded that the "Court's unworkable scheme for constitutionalizing the regulation of abortion" had had a debilitating effect, "not ... surprising . . . since the Court is not suited to the expansive role it has claimed for itself in the series of cases that began with Roe $v$. Wade."66

But notwithstanding the occasional strength of her rhetoric, Justice O'Connor has never questioned Roe's central premise that the liberty to choose abortion is fundamental, nor accepted Chief Justice Rehnquist's and Justice White's view that any state interest at any point in pregnancy may, if a state legislature chooses, outweigh a woman's right to choose. Quite to the contrary, she has sought to articulate a test which, again depending on how it is applied, could protect women at least against significant burdens of their privacy rights. How her approach could work, or fail and become a subterfuge for the Rehnquist sleight-of-hand approach, is the subject of this section.

\section{A. The Threshold Inquiry: Finding an "Undue Burden"}

Usually in constitutional law, the question whether a right has been infringed is easy: it's the question of whether the infringement is justified that is difficult. The mode of infringement may sometimes affect the scrutiny applied; for example, content-based speech regulation is more closely scrutinized by the Court than content-neutral laws that happen to burden speech. ${ }^{67}$ But rarely does the quantity of infringement matter; freedom of speech, for example has been held infringed by regulations that merely marginally increase its cost, ${ }^{68}$ or pose the potential for discriminatory application ${ }^{69}$-as well as by laws that prohibitively increase cost or actually discriminate.

Similarly in the abortion context, the Court has found strict scrutiny triggered not only when states criminalize abortion, but also

65476 U.S. 747, 814 (1986) (O’Connor, J., dissenting).

$66 \mathrm{Id}$. at 814-15 (O'Connor, J., dissenting).

67 Compare Police Dep't of Chicago v. Mosley, 408 U.S. 92, 99 (1972) (invalidating a regulation that discriminated on the basis of the subject matter of speech) with United States v. O'Brien, 391 U.S. 367, 376 (1968) ("[W]hen 'speech' and 'nonspeech' elements are combined in the same course of conduct, a sufficiently important governmental interest in regulating the nonspeech element can justify incidental limitations on First Amendment freedoms.").

68 See, e.g., Schneider v. State, 308 U.S. 147 (1939) (invalidating anti-leafletting law designed to prevent the public cost of cleaning up litter).

69 See, e.g., City of Lakewood v. Plain Dealer Publishing Co., 486 U.S. 750 (1988) (invalidating an ordinance allowing the mayor standardless discretion to license newsracks on city property). 
when regulations well short of criminalization encumber abortion with delay, administrative hurdles, or expense. ${ }^{70}$ Deterrents need not rise to the level of coercion to count as infringements of the right.

Justice O'Connor, however, has suggested that the quantity of burden an abortion restriction imposes should matter a great deal. In her Akron dissent, she argued that the Court's abortion cases required strict scrutiny only where a state imposes an "undue burden" on the abortion decision. ${ }^{71}$

What kind of burden must plaintiffs show? On the one hand, regulations whose actual impact on the abortion decision is minimal, speculative, or both are excluded from strict scrutiny, and subject only to review to determine if they are rationally related to a valid state objective. ${ }^{72}$ On the other hand, regulations that "drastically limit[]," or impose an "absolute obstacle" or "coercive restraint" trigger strict scrutiny. ${ }^{73}$ The key question, of course, is what happens to the myriad of regulations falling between these poles, which states pass, in many cases quite explicitly, to restrict abortion.

From Justice O'Connor's own opinions, it is clear that the threshold inquiry should be quantitative rather than qualitative: the issue is the amount of impact, not the justification for it. Justice O'Connor's opinions also make clear that the obstacle need not affect all women; that other women, or average women, or women who may be older and richer can continue to choose freely, or at all does not render the burden "due" on those whom it affects most.

The question, though, is not simply one of quantity, objectively measured. If the inquiry is to be fair, it must be conducted from the woman's point of view. The relevant assessment of burden must be hers, not a legislator's or judge's.

70 The Akron, 462 U.S. at 416 , and Thomburgh, 476 U.S. at 747, cases best illustrate this point.

71 See Akron, 462 U.S. at 453, 461-66 (O'Connor, J., dissenting).

72 In other contexts, Justice O'Connor has shown a similar inclination not to apply strict scrutiny to cases where the impact on fundamental rights is merely trivial or incidental. In Arcara v. Cloud Books, Inc., 478 U.S. 697 (1986), for example, the Court upheld the closing of a brothel that happened to be located in a bookstore. Justice O'Connor concurred, reasoning that strict scrutiny was not triggered: "Any other conclusion would lead to the absurd result that any government action that had some conceivable speech-inhibiting consequences, such as the arrest of a newscaster for a traffic violation, would require analysis under the First Amendment." Id. at 708 (O'Connor, J., concurring).

73 Akron, 462 U.S. at 464 (O'Connor, J., dissenting). 


\section{The Question of Degree}

At first glance, the term "undue burden" may seem to express a judgment rather than a description: the concept not that a burden is heavy but that it is too heavy. Justice O'Connor's own opinions suggest otherwise. She expressly rejected such a qualitative definition when given a chance, and adopted a quantitative definition instead.

In Akron, then-Solicitor General Rex E. Lee argued that only where an abortion regulation "unduly burdens" a woman's right to choose should the Court apply strict scrutiny to review that regulation. Under Lee's formulation, the Court should "accord heavy deference to the legislative judgment" in determining what constitutes an "undue burden." Justice O'Connor, while concluding that the "undue burden" test should define the threshold for strict scrutiny, took sharp issue with the Solicitor General's qualitative definition of that test. Justice O'Connor declared "undue burden" is a strictly quantitive concept:

'The 'unduly burdensome' standard is appropriate not because it incorporates deference to legislative judgment at the threshold stage of analysis, but rather because of the limited nature of the fundamental right that has been recognized in the abortion cases. ... [I]t is not appropriate to weigh the state interests at the threshold stage." 74

The measure of whether a burden is "undue" therefore, is not whether it is justified, but whether it is significant.

In determining whether a burden is "undue" in this sense, Justice O'Connor has treated one issue as squarely resolved by the Court's precedents: a regulation need not burden all women in order to trigger strict scrutiny. The right recognized in Roe is a right possessed by every pregnant woman. A regulation that "drastically limits" even one woman's freedom should trigger strict scrutiny. Justice O'Connor herself recognized in Akron that regulations affecting some but not all women can impose "undue burdens."75 While Roe was, in her analysis, unduly burdensome because it criminalized all abortions except those necessary to save the mother's life, the prohibition of saline amniocentesis struck down in Planned Parenthood of Central Missouri v. Danforth ${ }^{76}$ also constituted an undue burden even though it only affected women seeking second-trimester abortions, and

74 Akron, 462 U.S. at 465 n.10 (O'Connor, J., dissenting) (discussing amicus curiae brief for the United States).

$75 \mathrm{Id}$. at 464 (O'Connor, J., dissenting).

76428 U.S. 52 (1976). 
notwithstanding that the overwhelming majority of abortions occur during the first trimester. ${ }^{77}$ The same was true for the parental and spousal consent requirements that the Court invalidated in Danforth and Bellotti v. Baird: ${ }^{78}$ these regulations warranted strict scrutiny even though they would impose an "absolute obstacle" only to those women (surely a minority of some sort) who are both covered by the regulations (married or minors) and also unable to secure the requisite parental or spousal consent.

Problems of proof remain, however, even if the standard is so defined. How does a woman prove that she is being blocked, or limited, or burdened? While Justice O'Connor has expressed concern with regulations whose impact is speculative, at least at the time of suit, ${ }^{79}$ it is simply unfair, and unnecessary, to require that a woman actually sacrifice her constitutional liberty before she or anyone else can challenge a restriction on her freedom. The Court should not demand an unwanted child, or a woman maimed by an illegal abortion, as proof that strict scrutiny is warranted.

\section{The Question of Perspective}

Because Justice O'Connor's test is based on the obstacle to the woman making the abortion decision, the only appropriate perspective for assessing the burden is that woman's. Justice O'Connor herself recognized a similar point in the context of a possible state establishment of religion; the question is not whether a Christian might view a creche scene as religious, but whether a non-Christian would. ${ }^{80}$ So too, the question here is not whether a judge or a legislator or the law's perennial "reasonable man" would judge an increase in cost or a requirement of notification to be a "drastic limit." The question is whether a pregnant woman, or girl, would. ${ }^{81}$

It is not simply a matter of a man's perspective versus a woman's or, all too often, a girl's. Unwanted pregnancies strike harder at the poor and the young than at comfortable adults. Inadequate health

77 See id. at 79.

78443 U.S. 622 (1979).

79 See Akron, 462 U.S. at 466 (O'Connor, J., dissenting) (finding no "undue burden" in Akron's second-trimester hospitalization requirement where "there is no evidence in this case to show that the two Akron hospitals that performed secondtrimester abortions denied an abortion to any woman, or that they would not permit abortion by the D\&E procedure. . . In addition, there was no evidence presented that other hospitals in nearby areas did not provide second-trimester abortions.").

80 See Lynch v. Donnelly, 465 U.S. 668, 690-94 (1984).

81 Cf. S. Estrich, REAL RAPE (1987) (discussing the relevance of men's versus women's perspective on force and consent in rape). 
care, incomplete birth control information, and violence and abuse, are far more common realities for poor and young women than for middle class adults. Moreover, while a $\$ 50$ difference in cost may appear modest to most members of the Supreme Court, whose families are insured in any event, it is a lifetime's savings for a teenage girl. To forget her perspective could, quite literally, cost her life.

Nor is it fair to forget that the person facing the obstacle is likely desperate. Justice O'Connor recognized in Akron that the abortion decision is a "stressful one." It is particularly stressful for women who must face it alone, without the support of family, without the advice of a private physician, without the comfort of age and experience. It is precisely these women for whom the burdens of securing an abortion are already greatest, who are most often the targets and victims of restrictive abortion legislation. The undue burden test becomes a mockery if it permits legislatures to pass restrictions with little or no application to people like them, and then insist that their perspective should govern the scrutiny to be applied.

Adopting a woman's perspective, however, is not an excuse to use a woman's desperation against her. The fact that many women seeking abortions would go to great lengths, and sometimes do to avoid having a child they cannot take care of should not be grounds for allowing a state to regulate more. That is the problem with defining the "undue burden" test in terms of "absolute obstacles:" for a desperate woman, burdens which surely should be considered "undue" may not be absolute because of her desperation. To insist, even if only in theory, ${ }^{82}$ that a woman prove she has been blocked, or would be, goes beyond a measure of the burden. The only fair question is whether the obstacle or burden is, considered from her perspective, significant or substantial. To demand more is to turn logic on its head, effectively holding that the most desperate among us can, because of that, be burdened the most.

Which raises a final point of perspective: restrictions that, considered one by one by a court, may not appear undue are not experienced that way by a woman seeking an abortion. She experiences them all, and usually at once. A state should not be able to escape strict scrutiny by parsing an undue burden into a multi-part legislative package.

So long as every non-trivial burden is subject to strict scrutiny, the difference between a legislator's perspective and a woman's, or

82 See supra text accompanying note 79 (the Court should not require past injury to prove that the harm is not speculative). 
between one burden and a legislative package, does not matter so much: all burdens must be justified by a compelling state interest and narrowly tailored to serve that goal. But if a threshold is to be established before strict scrutiny is applied, then questions of perspective and aggregation become not only critical, but in many cases determinative. Fairly applied, the "undue burden" test can still provide a reasonable measure at least of potential protection to women; unfairly applied, it is an even easier route than the Webster plurality's to eviscerate women's rights.

\section{Questions of Application}

Justice O'Connor's application of the "undue burden" concept in practice has been far more troublesome than its invocation in the abstract. First, she has never acknowledged that significant cost increases constitute "burdens" on abortion. Yet, as every anti-abortion legislator well knows, one of the best ways to deter abortion is to raise the price. Hospitalization requirements, for example, make abortions significantly more expensive than they are in clinics. ${ }^{83}$ In Akron, Justice O'Connor pointed to only one case, Doe v. Bolton, ${ }^{84}$ in which the Court invalidated regulations she would have upheld. The regulations invalidated in Doe included, among others, a first trimester hospitalization requirement.

To be sure, Justice O'Connor's dispute with Doe may not have turned on her minimizing the costs of that requirement. The Court's decision, as Justice O'Connor correctly pointed out, was not based on an analysis of the regulation's impact on the abortion right, particularly among the poor for whom a many-fold increase in price is the functional equivalent of absolute prohibition. Rather, "[t]he Court clearly based its disapproval of these requirements on the fact that the State did not impose them on any other medical procedure apart from abortion." 85 This rationale for applying strict scrutiny is the one with which Justice O'Connor plainly takes issue.

In Akron itself, Justice O'Connor more explicitly confronted the issue of cost. In that case, the Court struck down a series of regulations as violative of Roe, and Justice O'Connor dissented. The key provision of the Ohio statute, at least for purposes of understanding Justice O'Connor's approach, was the requirement that doctors per-

83 See Turnock v. Ragsdale, 841 F.2d 1358 (7th Cir. 1988), cert. granted, 57 U.S.L.W. 3859 (1989). Ragsdale settled before oral argument.

84410 U.S. 179 (1973).

85 Akron, 462 U.S. at 464 n.9 (O'Connor, J., dissenting). 
form all second trimester abortions in hospitals. In striking down this requirement, the majority reasoned the rule imposed a "significant obstacle" for women because it would have substantially increased the cost of abortions because second-trimester abortions were rarely performed in Akron hospitals, and because it might force women to travel substantial distances. Justice O'Connor found the majority's reliance on increased costs and decreased availability "misplaced."86

It is possible to read Justice O'Connor's disagreement with the majority as a difference of view as to the factual showing required to establish a "substantial obstacle" or "undue burden." In her view:

[T] here [was] no evidence ... to show that the two Akron hospitals that performed second-trimester abortions denied an abortion to any woman, or that they would not permit abortion by the $\mathrm{D} \& \mathrm{E}$ procedure.... In addition, there was no evidence presented that other hospitals in nearby areas did not provide second-trimester abortions. $^{87}$

Regardless of availability questions, however, Justice O'Connor's answer to the Akron majority plainly ignored the cost question. In Webster, she at least recognized that cost differentials could be a significant factor, but her own position remains inconclusive. In rejecting the plurality's effort to manufacture a conflict with Roe, she focused on cost to distinguish the second trimester hospitalization requirement struck down in Akron from the fetal viability testing requirements upheld in Webster. ${ }^{88}$ The problem is that Justice O'Connor does not say how much of an increase would trigger strict scrutiny, even though from the perspective of a woman seeking an abortion, the cost of hospitalization plainly is a substantial obstacle. A second, perhaps even more troubling aspect of Justice

86 See id. at 466 .

87 Id. The Court has not required such a demonstration of foreclosed alternatives in other contexts. See, e.g., Schad v. Borough of Mt. Ephraim, 452 U.S. 61,76 (1981) (rejecting government's argument that those aggrieved by a nude dancing ban could always go elsewhere).

88 Justice O'Connor wrote:

The second-trimester hospitalization requirement struck down in Akron imposed, in the majority's view, "a heavy, and unnecessary, burden," more than doubling the cost of "women's access to a relatively inexpensive, otherwise accessible, and safe abortion procedure." By contrast, the cost of examinations and tests that could usefully and prudently be performed when a woman is 20-24 weeks pregnant to determine whether the fetus is viable would only marginally, if at all, increase the cost of an abortion.

Webster, 109 S. Ct. at 3063 (citations omitted). 
O'Connor's application of her "undue burden" test in Akron is her suggestion that health regulations may never constitute "undue burdens" and should escape strict scrutiny. According to Justice O'Connor, a health regulation, which may be based on physical, emotional, or psychological factors, "simply does not rise to the level of 'official interference' with the abortion decision." 89

Perhaps dicta in a dissent ought not be taken too seriously. Still, this statement flatly contradicts Justice O'Connor's own definition of the "undue burden" test. It goes well beyond any kind of quantitative measure of the burden imposed, substituting instead precisely the sort of qualitative deference to a legislature for which Justice O'Connor chastised Solicitor General Lee. It would, if taken literally, potentially rubber stamp any regulation that might be justified as "health-related" regardless of the magnitude of its impact on a woman's freedom to choose.

Moreover, Justice O'Connor's exemption of all health regulations from strict scrutiny would permit those that are merely pretextual a free ride. If the actual purpose of a supposed "health" regulation is to discourage abortion pure and simple, then it should not stand, though a mere rational-basis review will let it do so on the ground of a conceivable relationship to health. ${ }^{90}$ Those are appropriate questions for the justification stage: to preclude them at the threshold turns Justice O'Connor's approach entirely on its head.

\section{B. The Justification Stage}

Roe $v$. Wade held the "right of privacy . . . broad enough to encompass a woman's decision whether or not to terminate her pregnancy," "91 but the right is not absolute. The right to choose abortion, like free speech or free exercise of religion, places an additional burden on government to justify regulation. As the Court announced in Roe, the test is an exacting one: regulation of the abortion decision

89 Akron, 462 U.S. at 467 (O'Connor, J., dissenting).

90 Justice O'Connor herself has suggested that where burdens on speech are imposed on the pretext of some general regulatory interest, strict rather than deferential scrutiny is appropriate: "[i]f . . . a city were to use a nuisance statute as a pretext for closing down a bookstore because it sold indecent books . . . the case would clearly implicate First Amendment concerns and require analysis under the appropriate First Amendment standard of review." Arcara v. Cloud Books, Inc., 478 U.S 697,708 (1986). No less should be true for pretextual burdens on abortion.

91 Roe, 410 U.S. at 153-54. 
"may be justified only by a "compelling state interest" " to which it is "narrowly drawn." 92

That is a standard definition of "strict scrutiny." Roe's use of trimesters to guide the application of strict scrutiny has been more controversial than the standard itself. At the same time, though, critics of the trimester approach, Justice O'Connor included, have had far more success in attacking it than in proposing alternatives. While health regulations may fairly be subject to strict scrutiny regardless of the trimester in which the state imposes them, regulations that seek to preserve potential life pose a direct conflict with the very interest that triggers scrutiny. Justice $O^{\prime}$ Connor has yet to suggest a substitute for trimesters in this context.

\section{The Attack on Roe's Trimesters}

In Roe, the Court identified two state interests that might be deemed sufficiently "compelling" to limit a woman's fundamental right to choose abortion. The state, the Court found, "does have an important and legitimate interest in preserving and protecting the health of the pregnant woman," and "it has still another important and legitimate interest in protecting the potentiality of human life." 93

What is known, and criticized, as Roe's trimester analysis is the categorical balance that the Court struck between these two state interests and a woman's right to choose abortion. Emphasizing that abortion mortality rates are less than childbirth mortality rates until the end of the first trimester, the Court marked this point as the time when the State's interest in maternal health becomes sufficiently compelling to allow regulating abortion procedures on that basis. Until the point of "viability," defined as the point where the fetus could live outside the mother's womb, ${ }^{94}$ the Court held that the state's interest in preserving potential life was secondary to the mother's right to control her own body.

This balance has been subject to two sets of criticisms. Justice O'Connor has voiced both. First, she criticizes the trimester lines as legal constructs based on changing medical technology, putting Roe on a collision course with itself. ${ }^{95}$ Second, she criticizes the Roe tri-

92 Id. at 155.

93 Id. at 162.

94 The Roe Court fixed viability at between 24 and 28 weeks. See id. at 160 .

95 See Akron, 462 U.S. at 458 (O'Connor, J., dissenting). See generally Rhoden, Trimesters and Technology: Revamping Roe v. Wade, 95 YaLE L.J. 639, 640 n.8 (1986) 
mester framework as setting arbitrary points to recognize state interests as compelling.

The first critique is based on a view that as medical technology advances, abortions will be safer, thus moving the "maternal health" demarcation line later, but "viability" will come sooner, thus moving the "preservation of potential life line" earlier. As Justice O'Connor argued in Akron:

The Roe framework, then, is clearly on a collision course with itself. As the medical risks of various abortion procedures decrease, the point at which the State may regulate for reasons of maternal health is moved further forward to actual childbirth. As medical science becomes better able to provide for the separate existence of the fetus, the point of viability is moved further back toward conception .... The Roe framework is inherently tied to the state of medical technology that exists whenever particular litigation ensues. ${ }^{96}$

The "viability" line has, in fact, proven far more stable than either Roe's supporters or critics hoped or feared. "Neonates less than 24 weeks gestational age [the earliest point cited in Roe] have close to $0 \%$ survival rate . . . [B] efore [this point], the fetal organs, especially the lungs, are not sufficiently developed to permit extrauterine survival even with the most sophisticated technology currently available."97 The maternal safety line, though, most surely has moved. The Akron majority recognized this fact, citing findings that show abortion may be safer than childbirth up to gestational ages of 16 weeks. ${ }^{98}$ This movement, if not causing a collision, has forced the Court to confront whether the trimester lines are legally or medically based.

Or neither. The Akron majority, while acknowledging that the medical justification for Roe's demarcation line between the first and second trimester had disappeared, found it "prudent" to retain Roe's identification of the beginning of the second trimester as the approximate time when the State's interest in maternal health becomes sufficiently compelling to justify significant abortion restrictions. Not sufficiently "compelling," however, to justify Akron's second trimes-

(noting that while it has become customary to speak of Roe in terms of trimesters, the Roe Court itself framed its holding in terms of the first trimester and then of stages marked by viability; placing viability roughly at the end of the second trimester).

96462 U.S. at 458 (O’Connor, J., dissenting).

97 New York State Task Force on Life and the Law, Fetal Extrauterine SuRVivabiLITY 10, 12 (1988).

98 See Akron, 462 U.S. at 429 n.11. 
ter hospitalization requirement. Even in the second trimester, the Akron Court required a "reasonable medical basis" for regulations, and found it lacking where, as here, required hospitalization early in the second trimester "departs from accepted medical practice."99

That resolution only added fuel to Justice O'Connor's fire. Plainly, the usual advantage of clear lines is their predictability, but that advantage is lost when, even past the formal demarcation point, constitutionality turns on the medical practice of the day.

Although legislatures are better suited to make the necessary factual judgments in this area, the Court's framework forces legislatures, as a matter of constitutional law, to speculate about what constitutes 'accepted medical practice' at any given time. Without the necessary expertise or ability, courts must then pretend to act as science review boards and examine those legislative judgments. ${ }^{100}$

That was only the half of it. Justice O'Connor's concerns with the trimester analysis did not depend solely on its relationship to changing medical technology. For her, the "fallacy inherent in the Roe framework" was even more basic:

[J]ust because the State has a compelling interest in ensuring maternal safety once an abortion may be more dangerous than childbirth, it simply does not follow that the State has no interest before that point that justifies state regulation to ensure that firsttrimester abortions are performed as safely as possible. ${ }^{101}$

In the same vein, Justice O'Connor rejected limiting the state's interest in potential human life to the period after viability:

The state interest in potential human life is likewise extant throughout the pregnancy. In Roe, the Court held that although the State had an important and legitimate interest in protecting potential life, that interest could not become compelling until the point at which the fetus was viable. The difficulty with this analysis is clear: potential life is no less potential in the first weeks of pregnancy than it is at viability or afterward. At any stage in pregnancy, there is the potential for human life... . The choice of viability as the point at which the state interest in potential life becomes compelling is no less arbitrary than choosing any point before viability or any point afterward. ${ }^{102}$

99 Id.; id. at 434.

$100 \mathrm{Id}$. at 458 (O'Connor, J., dissenting).

101 Id. at 460 (O'Connor, J., dissenting) (citation omitted).

$102 \mathrm{Id}$. at 460-61 (O'Connor, J., dissenting). 
The next sections reply to these criticisms.

\section{The State Interest in Maternal Health}

Justice O'Connor is surely right that the state has some interest in protecting newly-pregnant women, as it does in protecting all citizens. Few would doubt, for instance, that state interest is sufficiently great to subject abortion clinics to reasonable licensing procedures, even in the first trimester. In fact, the Danforth Court unanimously upheld two statutory provisions requiring that even during the first trimester, women provide informed, written consent to abortions and physicians keep certain records. The Court upheld the regulations even though the state did not impose comparable requirements on most other medical procedures. ${ }^{103}$

Even if the Court abandoned the trimester approach, however, it should nonetheless strike down many abortion regulations passed in the name of health. Strict scrutiny requires not only a compelling interest in the abstract, but also that a regulation is in fact tailored to further it. As Justice O'Connor herself stated for the Court in City of Richmond v. J.A. Croson Co., ${ }^{104}$ "the mere recitation of a 'benign' or legitimate purpose" is simply not enough when infringement of fundamental rights is at stake. Under strict scrutiny, "simple legislative assurances of good intention cannot suffice."105 In Croson, the Court refused to allow a city council's general assertion of remedial purpose to justify disadvantaging non-minority applicants seeking to do business with the city. The Court looked into actual purpose and demanded that the government seek to further that purpose through narrowly tailored regulations. Surely, if the Court requires such an exacting inquiry before a city can deny business opportunities to whites, it can require nothing less before states burden women in the exercise of their fundamental rights. ${ }^{106}$

Indeed, in practice, fairly applying strict scrutiny to health regulations throughout pregnancy should produce roughly the same results as the much-maligned "trimester" approach. To be sure, under the Akron majority's view, "health" concerns could not justify

103 See Planned Parenthood of Central Missouri v. Danforth, 428 U.S. 52, 65-67, 79-81 (1976).

104109 S. Ct. 706 (1989).

$105 \mathrm{Id}$. at 724.

106 Indeed, given their relative strengths in the political process, the inquiry, if anything, should be far more exacting when women seeking abortions are disadvantaged than when whites (particularly white males) seeking business are. See infra notes 125-30 and accompanying text. 
significant obstacles in the first trimester, but then, it is hard to see how such obstacles could ever survive appropriately strict scrutiny. Regardless of one's point of view on trimesters per se, there is no reason why a state should be entitled to impose substantial health obstacles at a time when the safety risks are so minimal. Substantial obstacles "based" on health at that point are at least unnecessary and most likely pretextual. ${ }^{107}$ As such, these restrictions should fail strict scrutiny whether or not the Court invokes trimesters.

During every trimester, according to the majority approach, health regulations must indeed further health, and as Justice O'Connor's Webster approach suggests, they must not require doctors and health professionals to depart from standard practice. In principle, strict scrutiny could require nothing less.

Of course, as her Akron dissent clearly shows, Justice O'Connor remains concerned with the competence of a legislature, and then a court, to review medical technology and adapt it in a timely fashion to law. No one, however, is requiring any legislature to regulate for health purposes in ways that burden the abortion decision, particularly when abortion is and continues to be, safer than many other unregulated medical procedures. If legislatures nonetheless choose to regulate "for health reasons," it is fair to demand that their regulations actually further maternal health. Absent that fit, they are unnecessarily burdening fundamental rights, and where abortion restrictions depart from medical practice, that should trigger, loud and clear, the question of whether the stated justification was truly the motivating factor.

\section{The State Interest in Potential Life}

If taken only on its own terms, Justice O'Connor's conclusion that the state interest in protecting potential life exists throughout pregnancy is, like her view of the state interest in maternal health, not very controversial. What is controversial is whether courts must consider all regulations that further it automatically compelling. Importantly, Justice O'Connor has never joined the Chief Justice and Justice White in the latter proposition, and rightly so. ${ }^{108}$

States, and the federal government, have long regulated toxic substances in the work place which may cause harm to fetuses and

107 As Justice O'Connor herself noted in Croson, a chief purpose of the narrowtailoring inquiry is to " 'smoke out' " regulations whose stated goal is pretextual. See Croson, 109 S. Ct. at 721.

108 See Webster, 109 S. Ct. at 3057 (plurality opinion). 
probably should do more, provided that the means does not discriminate against women workers. ${ }^{109}$ States regularly impose criminal and civil penalties when a fetus, pre- or post-viability, dies because of intentional or negligent injury to a pregnant woman.

But it is not the case, scientifically at least, that "potential life is no less potential in the first weeks of pregnancy than it is at viability or afterward." 110 In the early weeks of pregnancy, the chances of "spontaneous abortion" (miscarriage) are as high as $20 \%$ to $30 \%$ or more, and they may be highest for unplanned and unwanted pregnancies, where intake of the drugs and medications that may contribute to miscarriage is likeliest. By the thirteenth week, as many as $90 \%$ of these miscarriages have occurred. Accordingly, even if some interest in potential life existed all along the continuum from fertilization to birth, surely its magnitude, and thus the balance of interests between woman and fetus, must alter along the way. ${ }^{111}$

Even more fundamentally, there is only one way to protect potential life before a fetus has the potential to survive outside the womb: forbid or discourage abortion. ${ }^{112}$ After viability, there are surely other ways abortion regulations can preserve an interest in potential life. For example, the state may require two doctors' presence or forbid saline procedures in late abortions to enhance survival rates if an attempted abortion turns into a live birth. Imposing any "undue burdens," or indeed any burdens at all, on a woman's right prior to viability in the name of preserving life, though, is to say that a woman has a right and then to take it away. By definition, her right is to control her bodily autonomy even at the expense of potential human life.

Every abortion regulation, including the absolute prohibition struck down in Roe, can be defended by its supporters as furthering the state's interest in preserving potential human life. To acknowledge that the state interest does not itself magically "appear" at the point of viability may comport with common sense, but that is not, after all, a fair statement of Roe's holding. The question Roe asked

109 See UAW v. Johnson Controls, 50 Fair Empl. Prac. Cas. (BNA) 1627 (7th Cir. 1989) (en banc); id. at 1650-55 (Posner, J., dissenting); id. at 1655-65 (Easterbrook, J., dissenting).

110 Akron, 462 U.S. at 461 (O'Connor, J., dissenting).

111 See Thormburgh, 476 U.S. at 778-79 (Stevens, J., concurring).

112 At least that approach is the only way an abortion regulation can serve an interest in potential life. Prior to viability, regulation of a pregnant woman's nutrition, exercise, ingestion of dangerous substances, and health habits might serve an interest in protecting the quality of "potential life," but it raises many other problems. See Field, Controlling the Woman to Protect the Fetus, 17 L. MED. \& HealTH CARE 114, 144 (1989). 
and answered, here as in the case of a state's interest in maternal health, was not whether the state might have any valid interest cognizable in any setting, but rather when, if at all, the Court could consider the state interest sufficiently "compelling" to override a woman's right to have an abortion. It was that question to which viability provided the answer.

Scrupulous application of traditional strict scrutiny should, in certain cases, produce the same result as the Court's viability line. After viability, requiring a second physician may in fact further the state interest: he may help save the life of the neonate. Before viability, by definition, he could not. The only way the regulation preserves potential human life is by making abortions more expensive and therefore discouraging if not blocking them. That will be true of every regulation that seeks to preserve human life prior to viability. In that sense, the disagreement between Justice O'Connor and the Roe majority may, ultimately, be a disagreement about whether recognizing a fundamental right limits the state's ability to block its exercise.

Plainly, even if it decided that a calendar setting is not an appropriate demarcation point, the Court would still have to find some standard other than asking whether any given regulation "reasonably relates" to preserving potential life. Without an alternative, the answer would always be yes, even for criminal prohibition in cases of rape and incest, or where the mother's life is at stake. Such scrutiny is not only not strict; it negates the fundamental right that triggers it.

Unlike the Chief Justice and Justice White, Justice O'Connor cannot intend this result. In fact, her own emphasis on the threshold inquiry into the burden's "undueness" indicates that she does not. Justice O'Connor's inquiry would be irrelevant if every abortion regulation could be found to serve a compelling interest in potential life. Therefore, she must think that many "undue burdens" are unjustified even though states impose them in the name of preserving potential life. But the question remains, whatever Justice O'Connor's approach requires in theory, how it works in practice.

\section{Questions of Application}

In Planned Parenthood v. Ashcroft, decided the same day as Akron, ${ }^{113}$ Justice O'Connor once again dissented from the Court's decision that a second trimester hospitalization provision was uncon- 
stitutional. She stated: "Assuming, arguendo, that the requirement was an undue burden, it would nevertheless 'reasonably relat[e] to the preservation and protection of maternal health." "114 She reached the same conclusion, following the same analysis, with respect to Missouri's requirement, upheld by the majority, that a second physician be present to attend to the fetus in a post-viability abortion: "I agree that the second physician requirement ... is constitutional because the State possesses a compelling interest in protecting and preserving fetal life, but I believe that this state interest is extant throughout pregnancy. I therefore concur . . . ${ }^{115}$

This statement, along with a similar one in Akron approving a twenty-four hour waiting period which the Court struck down, ${ }^{116}$ raises some difficult questions about Justice O'Connor's approach. In $A k r o n$, she described the test as an exacting one, but her cursory application of it, in the arguendo form to be sure, does not require careful tailoring to a compelling interest. Rather, it mandates no more than a "reasonable relationship." As argued above, one could justify virtually any regulation, including one that blocked abortions completely or in practice, as "reasonably related" to preserving potential human life. Justice O'Connor's citation of Roe for the "reasonable relationship" language is somewhat disingenuous, because Roe recognizes this interest as compelling only in the third trimester. Justice O'Connor, by contrast, emphasized in Ashcroft as in Akron that she considers the state interest in preserving potential life, like its interest in maternal health, to be "extant" throughout pregnancy. But equally compelling? Regardless of the countervailing interest? Regardless of proof of impact or intent?

It is one thing to require a second physician to protect potential life after viability. Imposing this same requirement in the first trimester, however, would only increase abortion's cost without creating any countervailing benefits to the fetus. Abandoning the trimester approach without taking these differences into account effectively overrules Roe, and replaces it with a rule of nine months of deference to any regulation that anyone can relate to safety or potential life. That rule is precisely what Texas argued for in Roe, what Solicitor General Lee sought in Akron, and what Chief Justice Rehnquist attempted in Webster. It is not what Justice O'Connor's approach seems to require. But neither her $A k r o n$ or $A$ shcroft opinion elucidates

$114 I d$. at 505 (O'Connor, J., concurring in part and dissenting in part) (citing Roe, 410 U.S. at 113).

115 Id.

116 See Akron, 462 U.S. at 473-74 (O'Connor, J., dissenting). 
her answers to the inevitable need for some other means to strike the balance.

Justice O'Connor's dissenting opinion three years later in Thornburgh v. American College of Obstetricians E Gynecologists ${ }^{117}$ does little to resolve these issues. Thomburgh went no further in the district court than the denial of preliminary relief. The bulk of Justice O'Connor's dissent explains her disagreement with the majority's decision to review facially and strike down a number of Pennsylvania provisions. In Justice O'Connor's view, the Court of Appeals, if it disagreed with the district court's assessment of the "likelihood of success on the merits," should have remanded with an order to grant pieliminary relief. Instead, the Court of Appeals reviewed and permanently enjoined a number of the statute's provisions. The Supreme Court affirmed. "In so doing," Justice O'Connor stated, "the Court prematurely decides serious constitutional questions on an inadequate record, in contravention of settled principles of constitutional adjudication and procedural fairness." 18

The procedural dispute between the majority and Justice O'Connor is itself an almost natural outgrowth of the differences between her approach and Roe. Under Justice O'Connor's approach, the regulations' actual impact is the crucial determinant of whether a state has imposed an "undue burden" requiring strict scrutiny. By contrast, for the majority, Roe's trimesters in effect impose limits on certain kinds of regulation even if the impact is lower or more speculative than an O'Connor "undue burden." This difference, at least in part, explains why the factual record and potentially narrowed interpretations that a remand might provide would be more determinative for her than for the majority.

There is plainly another factor at work as well. In both Thormburgh and Akron, Justice O'Connor disagreed with the majority as to the permissible requirements for informed consent. In Akron, the question was whether the state could require a doctor to give these warnings himself, or impose a 24-hour waiting period between consenting to an abortion and having one. In Thomburgh, her disagreement centered on the requirement that someone be available to provide a woman seeking an abortion with information about the risks of the procedure, fetal characteristics, the availability of medical assistance benefits, and the father's legal responsibility. In striking down these provisions, the majority ruled that the state's purpose 
was to limit abortions, and the effect was to increase women's anxiety and to intrude on the doctor-patient relationship.

Justice O'Connor is plainly unmoved by such factors. To be sure, she was careful to point out that requiring health professionals to provide such information, let alone to read it aloud to illiterate women, raised first amendment concerns. She also noted that if the material was inaccurate and inflammatory, the requirement might have been an "undue burden" even if the woman requested to see the information. Still, Justice O'Connor plainly does not believe that women have any constitutional right to be shielded from the painful realities of their choice. Even though an overnight waiting period, accurate information, detailed warnings and the like make it more difficult for women who choose to abort, this is not the sort of difficulty Justice O'Connor sees as an excessive burden.

Justice O'Connor's motives in this regard hardly appear punitive. She, like all of us, plainly sees the abortion decision as something more and something different than other trips to the doctor. We cannot imagine that any woman, particularly any woman who has made that decision, would disagree. Even assuming, though, that states may affirmatively encourage childbirth through selective subsidy, as Justice O'Connor makes clear that they are entitled to do, ${ }^{119}$ it is another matter to seek this goal by imposing obstacles on women who wish to exercise their constitutional right to disagree with this particular state policy. Harris v. McRae, ${ }^{120}$ upon which Justice O'Connor relies to argue that states may encourage childbirth without "fine-tuning" their statute "to encourage or facilitate abortion," involved an affirmative government decision to provide funds to poor women for childbirth, but not for abortion. Whatever position one takes on the decision to fund, it is surely different than a state policy which seeks to "encourage childbirth" by taxing abortion. Even assuming that rewards may be appropriate to secure the end of childbirth, punishments should not.

\section{The Political Process: Not To Be Trusted}

On October 13, 1989, The New York Times declared that the tide

119 "[S]tate action 'encouraging childbirth except in the most urgent circumstances' is 'rationally related to the legitimate governmental objective of protecting potential life.' "Akron, 462 U.S. at 466 (O'Connor, J., dissenting) (quoting Harris v. McRae, 448 U.S. 297, 325 (1980)). For criticism of the Court's refusal to find selective subsidies an infringement of the abortion right, see Sullivan, Unconstitutional Conditions, 102 HaRv. L. REv. 1413, 1416, 1474, 1500-03 (1989).

120448 U.S. 297 (1980). 
had turned in the political process on abortion. ${ }^{121}$ The Florida legislature, in special session, rejected a series of proposals to restrict abortion, and Congress voted to expand abortion funding for poor women to cases of rape and incest. And most stunningly of all, the Attorney General of Illinois on November 2, 1989, settled a pending challenge to Illinois' abortion clinic regulation rather than risk winning his case in the United States Supreme Court. These events have triggered the assessment that the post-Webster pro-choice mobilization has succeeded. Which raises the question: why not leave these matters to the political process?

The short answer, of course, is that we don't leave freedom of speech or religion or association to the political process, even on good days when the polls suggest they might stand a chance, at least in some states. The very essence of a fundamental right is that it "depend[s] on the outcome of no elections." 122

The long answer is, as always, that fundamental liberties are not occasions for the experimentation that federalism invites. The right to abortion should not depend on where you live and how much money you have for travel. ${ }^{123}$ And, regardless of our recent, at longlast successes, the reality remains that the political process is to be trusted the least where, as here, it imposes burdens unequally.

The direct impact of abortion restrictions falls exclusively on a class of people that consists entirely of women. Only women get pregnant. Only women have abortions. Only women will endure unwanted pregnancies and adverse health consequences if states restrict abortions. Only women will suffer dangerous, illegal abortions where legal ones are unavailable. And only women will bear children if they cannot obtain abortions. ${ }^{124}$ Yet every restrictive abortion law has been passed by a legislature in which men constitute a numerical majority. And every restrictive abortion law, by definition, contains an unwritten clause exempting all men from its strictures.

121 See Apple, An Altered Political Climate Suddenly Surrounds Abortion, N.Y. Times, Oct. 13, 1989, at A1, col. 4; see also Berke, The Abortion-Rights Movement Has Its Day, N.Y. Times, Oct. 15, 1989, § 4 at 1 , col. 1 .

122 West Virginia Bd. of Educ. v. Barnette, 319 U.S. 624, 638 (1943).

123 Even if only ten or eleven states were to preclude abortion within their borders, many women would be held hostage there by the combination of geography, poverty, and youth. This situation would be no more tolerable than the enforcement of racial segregation in a "mere" ten or eleven states in the 1950s.

124 See Michael M. v. Sonoma County Superior Court, 450 U.S. 464, 473 (1981) ("[V]irtually all of the significant harmful and inescapably identifiable consequences of teenage pregnancy fall on the young female"). 
As Justice Jackson wrote, legislators threaten liberty when they pass laws that exempt themselves or people like them: "The Framers of the Constitution knew, and we should not forget today, that there is no more effective practical guaranty against arbitrary and unreasonable government than to require that the principles of law which officials would impose upon a minority must be imposed generally." ${ }^{25}$ The Supreme Court has long interpreted the equal protection clause to require even-handedness in legislation, lest the powerful few too casually trade away for others key liberties that they are careful to reserve for themselves.

For example, in striking down a law permitting castration of recidivist chicken thieves but sparing white collar embezzlers the knife, the Court implied that, put to an all-or-nothing choice, legislators would rather sterilize no one than jeopardize a politically potent class. ${ }^{126}$ In the words of Justice Jackson: "There are limits to the extent to which a legislatively represented majority may conduct biological experiments at the expense of the dignity and personality and natural powers of a minority-even those who are guilty of what the majority defines as crimes." 127

At least there should be. Relying on state legislatures, as Chief Justice Rehnquist would, to protect women against "abortion regulation reminiscent of the dark ages,"128 ignores the fact that the overwhelming majority of "those who serve in such bodies"129 are biologically exempt from the penalties they are imposing.

The danger is greater still when the subject is abortion. The lessons of history are disquieting. Abortion restrictions, like the most classic restrictions on women seeking to participate in the worlds of work and ideas, have historically rested on archaic stereotypes portraying women as persons whose "paramount destiny and mission ... [is] to fulfill the noble and benign office of wife and mother."130 Legislation prohibiting abortion, largely a product of the years

125 Railway Express Agency v. New York, 336 U.S. 106, 112 (1949) (Jackson, J., concurring).

126 See Skinner v. Oklahoma, 316 U.S. 535 (1942). Cf. Epstein, The Supreme Court, 1987 Term: Foreword: Unconstitutional Conditions, State Power, and the Limits of Consent, 102 HaRv. L. REv. 4 (1988) (arguing that enforcement of unconstitutional conditions doctrine similarly functions to put legislatures to an all-or-nothing choice).

I27 Skinner, 316 U.S. at 546 (Jackson, J., concurring).

128 Webster, 109 S. Ct. at 3045.

129 Id.

130 Bradwell v. Illinois, 83 U.S. (16 Wall.) 130, 142 (1873) (Bradley, J., concurring). 
between 1860 and 1880 , reflected precisely the same ideas about women's natural and proper roles as other legislation from the same period, long since discredited, that prohibited women from serving on juries or participating in the professions, including the practice of law. ${ }^{131}$ And modern studies have found that support for laws banning abortion continues to be an outgrowth of the same stereotypical notions that women's only appropriate roles are those of mother and housewife. In many cases, abortion laws are a direct reaction to the increasing number of women who work outside of the home. ${ }^{132}$ Those involved in anti-abortion activities tend to echo the wellknown views of Justice Bradley in Bradwell:

Men and women, as a result of ... intrinsic differences, have different roles to play. Men are best suited to the public world of work, whereas women are best suited to rearing children, managing homes, and loving and caring for husbands. . . . Mothering, in their view, is itself a full-time job, and any woman who cannot commit herself fully to mothering should eschew it entirely. ${ }^{133}$

131 See J. Mohr, Abortion in America: The Origins and Evolution of National Policy, 1800-1900, at 168-72 (1978). To many of the doctors who were largely responsible for abortion restrictions, "the chief purpose of women was to produce children; anything that interfered with that purpose, or allowed women to 'indulge' themselves in less important activities, threatened ... the future of society itself." Id. at 169. The view of one such nineteenth century doctor drew the parallel even more explicitly: he complained that "the tendency to force women into men's places" was creating the insidious new idea that a woman's "ministrations . . . as a mother should be abandoned for the sterner rights of voting and law making." Id. at 105; see also L. Gordon, Woman's Body, Woman's Right: A Social History of BIRTH CONTROL IN AMERICA (1976) (chronicling the social and political history of reproductive rights in the United States).

132 See generally K. Luker, Abortion AND the Politics of Motherhood 192-2 15 (1984) (describing how the abortion debate, among women, represents a "war" between the feminist vision of women in society and the homemaker's world view); Luker, Abortion and the Meaning of Life, in ABortion: Understanding DifFerences 25, 31-33 (S. Callahan \& D. Callahan eds. 1984) (concluding that "[b]ecause many prolife people see sex as literally sacred, and because, for women, procreative sex is a fundamental part of their "career ... abortion is, from their [the prolife] point of view, to turn the world upside down").

133 Luker, supra note 132 at 31 . It is, of course, precisely such stereotypes, as they are reflected in legislation, which have over and over again been the focus of this Court's modern equal protection cases. See, e.g., Califano v. Goldfarb, 430 U.S. 199, 206-07 (1977) ("Gender-based differentiation ... is forbidden by the Constitution, at least when supported by no more substantial justification than 'archaic and overbroad' generalizations."); Weinberger v. Wiesenfeld, 420 U.S. 636, 645 (1975) ("Gender-based generalizations" that men are more likely than women to support their families "cannot suffice to justify the denigration of the effects of women who do work:..."); Stanton v. Stanton, 421 U.S. 7, 14 (1975) ("A child, male or female, is still a child. No longer is the female destined solely for the home and the rearing of the family, and only the male for the marketplace and the world of ideas."); 
But the lessons of history are not limited to the powers of enduring stereotypes. History also makes clear that a world without Roe will not be a world without abortion but a world in which abortion is accessible according to one's constitutional caste. While affluent women will travel to jurisdictions where safe and legal abortions are available, paying whatever is necessary, restrictive abortion laws and with them, the life-threatening prospect of back-alley abortion, will disproportionately descend upon "those without . . . adequate resources" to avoid them. ${ }^{134}$ Those for whom the burdens of an unwanted pregnancy may be the most crushing-the young, the poor, women whose color already renders them victims of discrimination-will be the ones least able to secure a safe abortion.

In the years before Roe, "[p]oor and minority women were virtually precluded from obtaining safe, legal procedures, the overwhelming majority of which were obtained by white women in the private hospital services on psychiatric indications." 135 Women without access to safe and legal abortions often had dangerous and illegal ones. According to one study, mishandled criminal abortions were the leading cause of maternal deaths in the $1960 \mathrm{~s},{ }^{136}$ and mortality rates for African-American women were as much as nine times the rate for white women. ${ }^{137}$ To trust the political process to protect these women is to ignore the lessons of history and the realities of power and powerlessness in America today.

In the face of such lessons, those who would have us put our faith in the political process might first want to look a little more closely at the victories which are said to support such a choice. The Florida legislature's rejection of proposed abortion restrictions came days after that state's highest court held that the State Constitution

Frontiero v. Richardson, 411 U.S. 677, 684 (1973) ("[O]ur Nation has had a long and unfortunate history of sex discrimination ... which in practical effect put women, not on a pedestal, but in a cage.").

134 Griswold v. Connecticut, 381 U.S. 479, 503 (1965) (White, J., concurring).

135 Polgar \& Fried, The Bad Old Days: Clandestine Abortions Among the Poor in New York City Before Liberalization of the Abortion Law, 8 FAM. Plan. PERSP. 125 (1976); see also Gold, Therapeutic Abortions in New York: A 20- Year Review, 55 Am. J. Pub. Health 964, 66 (1965) (noting that the ratio of legal hospital abortions per live birth was five times more for white women than for women of color, and twenty-six times more for white women than for Puerto Rican women in New York City from 1951-62); Pilpel, The Abortion Crisis, in THE CASE FOR LEgALIzed ABORTION Now 97, 101 (Guttmacher ed. 1967) (noting that $93 \%$ of in-hospital abortions in New York State were performed on white women who were able to afford private rooms).

136 See Niswander, Medical Abortion Practices in the United States, in ABOrtion AND THE LAW 37, 37 (D. Smith ed. 1967).

137 See Gold, supra note 135, at 964-65. 
protects the right to choose abortion, rendering the entire session, by the press' verdict before it began, symbolic at best. The session was still a triumph, but hardly one in which the courts were beside the point. And while extending funding to cases of rape and incest would have been a step forward, the narrowness of the victory and the veto of the resulting legislation should give pause, at least. ${ }^{138}$

We believe that energizing and mobilizing pro-choice voters, and women in particular, is vitally important on its own terms. We hope, frankly, that with apportionment approaching in 1990, that mobilization will affect issues well beyond abortion. We hope more women will find themselves running for office and winning. We hope pro-choice voters and the legislators they elect will attack a range of issues of particular importance to women, including the attention that children receive after they are born.

But we have no illusions. We will lose some along the way. Young and poor and minority women will pay most dearly when we do. That's the way it is in politics. That's why politics should not dictate constitutional rights. That's why women need Justice Sandra Day O'Connor so badly.

138 Requiring prompt reporting of cases of rape and incest to criminal authorities, measured in terms of days if not hours, as the White House has suggested, is to ignore study after study that has found precisely such cases among the least often reported to the police. Yet late reporting, which should be encouraged, becomes grounds to deny funding, and excludes altogether those who fear, often with reason, to report at all. The pain and suffering of brutal victimization and of an unwanted pregnancy are in no way affected by the speed of the initial criminal report. A small victory, indeed.

President Bush vetoed the legislation on October 21, 1989. The House vote to override was 231-191, short of the necessary two thirds majority. See 135 Cong. REc. H7482-95 (daily ed. Oct. 25, 1989). 
